\title{
For a novel identification of the 'first palace of the kings of Egrisi' in Nokalakevi-Archaeopolis
}

\author{
Davit Lomitashvili* Nikoloz Murghulia** Besik Lordkipanidze** Tamila Kapanadze** \\ * Georgian National Agency for Cultural Heritage Preservation \\ *7 Tabukashvili Ave., 0105, Tbilisi, Georgia \\ *dlomitashvili@gmail.com \\ ** Georgian National Museum Simon Janashia Museum of Georgia \\ **3 Rustaveli Ave., 0105, Tbilisi, Georgia \\ **nikomurgulia@yahoo.com, , beso.lort@gmail.com, tamilakapanadze555@gmail.com \\ DOI: https://doi.org/10.52147/2667-9353/2021-1-23-31
}

\begin{abstract}
Because of the complicated foreign policy in the fourth century (regular attacks of the Goths and Huns on Roman Empire, the rise of Persia and subordination of Kartli, Armenia and Albania), Rome was unable to exert proper control over its eastern provinces, including the eastern Black Sea coast and, accordingly, it was compelled to put up with the Lazis becoming more and more active in western Georgia [Muskhelishvili 2012:39]. Apparently, the Lazis evaluated the existing situation properly and gradually made their neighboring tribes of the Apsils, Abazgs and Sanigs subordinate to them [Lomouri 2011:119-120]. Unification of the western Georgian tribes by the Lazis and formation of a strong kingdom was in the interests of the Roman Empire too. Scholars suggest that Rome encouraged this process, rather than hindering it, because presence of a strong kingdom in western Georgia which had control over various passes and fortified cities on the Black Sea coast would serve as a defensive barrier for eastern provinces of Rome from northern nomadic tribes [Melikishvili 1970:556-557; Lomouri 2011:120; Muskhelishvili 2012:39]. Procopius of Caesarea puts special emphasis on this situation. According to him, "For the barbarians inhabiting the Caucasus Lazika is just an obstacle" [Procopius of Caesarea 1965:94].

Thus, from the third century, the Lazis gradually annexed the tribes residing in western Georgia and laid foundation for the kingdom of Lazika (Egrisi), whose borders approximately fell within the limits of western Georgia (Fig. 1).

The king of Lazika had subordinated the neighboring tribes, but, on the other hand, formally it was a vassal of the Roman (Byzantine) emperor. According to Procopius of Caesarea, the Lazis "were Romans' subordinate, but they did not pay any tribute or submit to them. The only thing they did was that when their king died, the Roman king would send an heir to the throne, or the symbol of power, to them. The latter would rigorously protect the borders of this country together with his subordinates so that the hostile Hunns would be unable to invade Roman lands from the Lazis' bordering Caucasus Mountains passing through Lazika. They firmly protected them without getting any money or army from the Romans and did not go to war with the Romans either [Procopius of Caesarea 1965:72-73].

It is obvious that despite gaining factual independence, Romans still had considerable influence on western Georgia. It is not surprising - from the first century BC, after Pompey campaigned against Colchis and later (in the first-second cc AD) Rome deployed garrisons on the Black Sea coast, Rome gained a firm foothold in western Georgia. Analysis of archaeological material shows that this influence was not only political, but economic and cultural as well. For instance, the inland area of western Georgia yielded a large number of Roman coins of the first three centuries of the common era. Among them remarkable is a hoard of silver coins of the second-third centuries (907 items) discovered in Village Eki (Senaki Municipality) in 1971. It included a drachma of King Orod II of Parthia (57-38) and didrachmas and denarii minted in the names of Roman emperors Nerva, Trajan, Adrian, Antoninus Pius, Lucius Verus, Commodus, Pertinax, Niger, Septimius Severus and so on. 774 coins of the Eki hoard are struck in the mint of Caesarea, 131 - in the mints of Rome and those of the eastern provinces of Roman Empire, and the rest - in other provinces [G. Dundua, V. Tsirghvava 1971:42:45]. This and other contem-
\end{abstract}


poraneous discoveries prove that in the late Roman period Roman influence in western Georgia, especially in its western regions, was really strong.

Key words: Nokalakevi, Archaeopolis, kings' palace, praetorium, Roman Empire

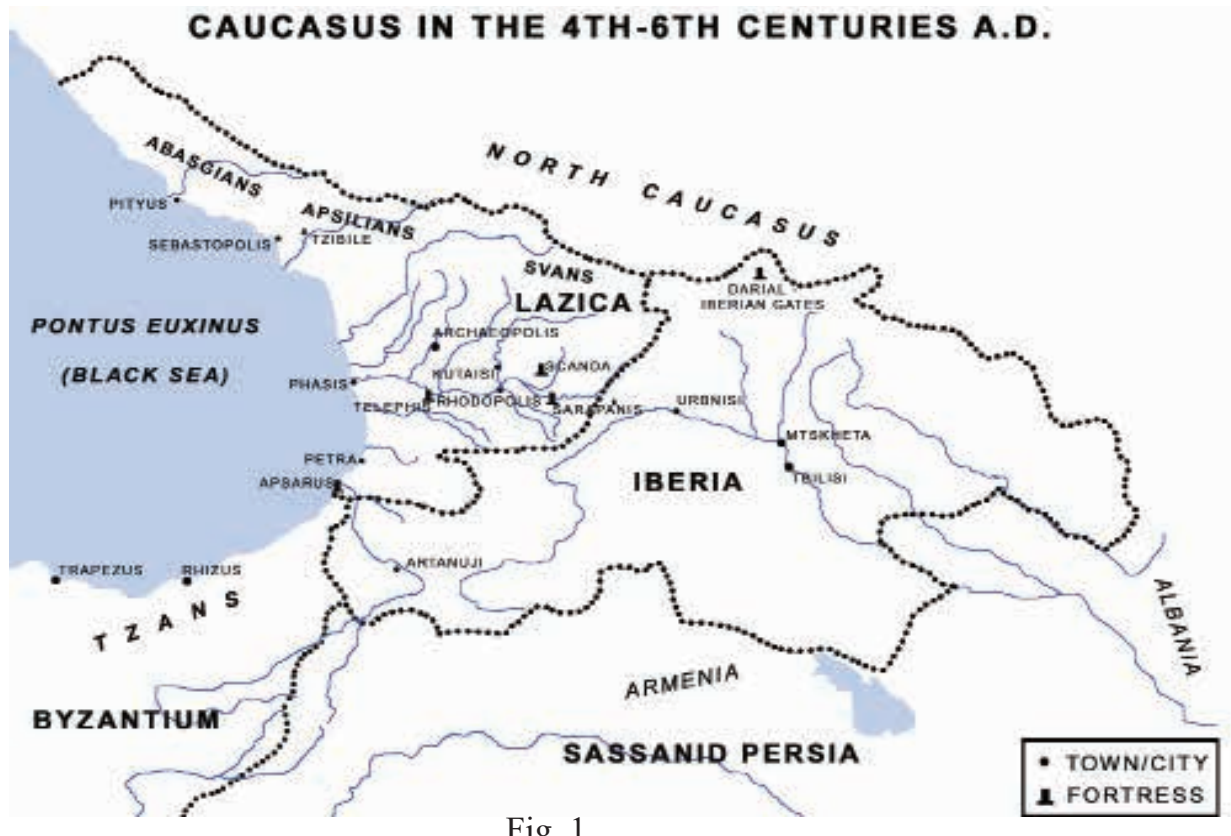

Fig. 1

City-Site of Nokalakevi. On the turn of the third-fourth centuries, the authorities of the newly formed Kingdom of Egrisi founded the capital city in the middle of the country. It is situated in the present village of Nokalakevi in Senaki Municipality and has long been identified with historical Tsikhe-Goji-Archaeopolis in historical science [for more detail see: N. Lomouri 1981:18-45].

There are three building periods on the city-site - the beginning of the fourth century, early fifth century and the 530s [N. Murghulia 2007:67-8]. All three building layers expose Roman-Byzantine influence. It is particularly obvious in the building layers of the sixth century, which is not surprising: presumably, remains of the palace of this period preserved at the city-site of Nokalakevi and the fortifications built of blocks were constructed on the order of the Byzantine emperor Justinian while he was preparing for the war against Iran [N. Murghulia 2012:209]. As far as the first and the second fortifications and other contemporaneous architecture are concerned, they must have been built by the Lazis, as in the fourth-fifth centuries the kingdom of Egrisi is independent and is capable of conducting construction itself, but not of such large-scale as it is represented in the third fortified wall built of blocks [Murghulia 2007:68-73]. The city-site yielded structures of the same fourth-fifth centuries where Roman influence is rather vivid. Particularly outstanding are a classical Roman-type bathhouse (with cold, warm and hot compartments) and early-Christian-period hall-type and threenave basilica-type churches typical of Roman epoch, which are similar to the churches of the Near East and Roman Empire. It should also be emphasized that the fourth-century hall-type church of Nokalakevi is analogous with its contemporaneous church revealed in Roman Pitiunt [Zakaraia, Kapanadze 1991:165-167], which, in itself, reflects the degree of influence of Roman architecture and, generally culture on the inland areas of Colchis.

As it has already been mentioned, as a result of long-term research, alongside the fourth-sixth century towers and fortifications, Nokalakevi expedition revealed, cleaned and investigated several structures: six churches, two bathhouses, two palaces, barracks, a tunnel, kilns for burning lime and clay, a water reservoir, walls separating districts of the city and residences of a commander [Zakaraia, 
Kapanadze 1991:7-113; 165-228]. It clearly shows that Nokalakevi was a typical urban center with all of its constituent parts (Fig. 2).

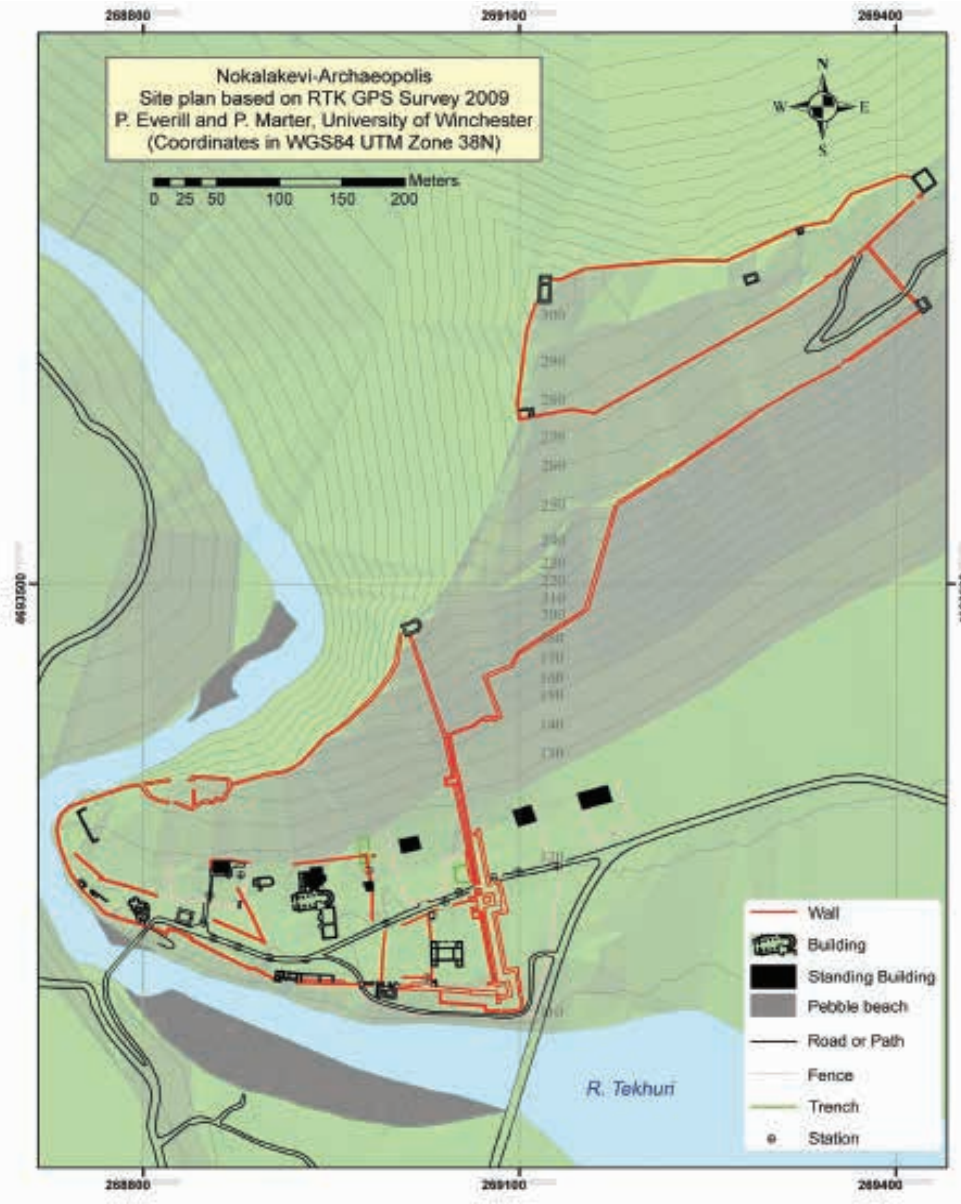

Fig. 2

South-east part of the city-site. The south-east part of the lower terrace of the city-site from the public bathhouse to the east fortifications should be considered separately. Three significant architectural objects were revealed in this section as a result of archaeological excavations:

Barracks which are annexed to the southern fortifications from the public bathhouse to the southern gate (Fig. 3). They are arranged in one line and expose the architecture typical of a barrack-type military structure. The majority of late-Roman - early- Byzantine barracks have a similar plan. Therefore, there is no doubt about the function of these structures; moreover, they are arranged along the fortification.

A circular kiln which had been built into the corner of one of the fortifications separating the inner districts in the south-east quarter of the city (Fig. 4). Presumably, it was a kiln for burning lime and was intensively used during long-lasting and repeated construction and restoration works of the city. In addition, its situation is not surprising either. It had been arranged near the main fortifications where large volume works were conducted.

The first palace of the kings of Egrisi is also situated in the south-east quarter of the city (Fig. 5-6), in its central part. Its excavation started in 1978 [Zakaraia 1987:59-60]. According to the initial interpretation of the members of the expedition, it must have been barracks, but later, studying the characteristic features of the structure led P. Zakaraia to the opinion that they were dealing with the remains of the first palace of the kings of Egrisi. Specifically, P. Zakaraia notes: "At first we thought these were "barracks, or the structure for housing a garrison. However, on completion of the excavations we were convinced that it was a palace" (Zakaraia 1987:59). He adds, "the thing we can clearly see so far is a large rectangle whose center is a big hall with open balconies along the longitudinal sides. Three rooms are arranged at both east and west ends... the walls are $75-85 \mathrm{~cm}$-wide, while the width of some walls outside the palace is $40-50 \mathrm{~cm}$. We believe that the size of the mentioned walls suggests that they were single-storey structures, while the first size points to two-storied ones. In itself, the kings' palace must have had at least two floors" [Zakaraia 1987:60-61].

P. Zakaraia's and T. Kapanadze's opinion about the function of this structure was shared by B. Lordkipanidze, who noted that the palace was built simultaneously with the original fortification of the city. He added that although the extant remains of the palace do not allow us to provide an accurate date, by all its parameters it must belong to the early stage of functioning of the city [B. Lordkipanidze 1993:180]. Furthermore, while discussing the second palace of the city-site, he remarks that simul- 
taneous functioning of the two palaces is rather doubtful, although the second palace was built later [Lordkipanidze B. 1993:191]. In our opinion, the suggestion that presence of two palaces would be great luxury sounds remarkable and acceptable in this case.

We consider it reasonable to define the number of floors based on the thickness of the walls. However, there are certain issues that stop us, members of Nokalakevi expedition, from identifying the structure in question with a palace. First of all, let us consider situation of the 'palace'. As it was already noted, the structure is set out in the south-east corner of the city-site (Fig.7), so that it is distanced from both the eastern and southern fortifications by 20 meters. It should also be emphasized that the eastern and south-eastern parts of the city-site were the weakest and less secured (Murghulia 2012:198-199). Therefore, it was from these sides that the city was attacked physically and with various types of launchers. Resulting from the above mentioned, building of the king's residence in the least protected area is hardly likely. This opinion is based on the logic of the city- planning, as well as fortification principles of the Classical epoch and the Middle Ages. Furthermore, it is notable that no remains of palaces are found at such unprotected places in contemporaneous city-fortresses, e.g., in Kutaisi, Tbilisi and other sites (Zakaraia P. 2002:41-42, 100-101, Lanchava 0. 2007:114-115].

There arises a question of what the function of a large structure (outside dimensions: $20 \mathrm{~m}$ (SN) $x$ $24 \mathrm{~m}(\mathrm{WE})$, presumable a two-storey building set out in the south-east part of the city, was if it was not a palace? Initially, the excavators presumed there were barracks here, but, in our opinion, it can be excluded due to two reasons: 1 . The expedition revealed a long line of structures along the southern fortifications of the city-site, which were reasonably identified as barracks (Fig.3). Barracks of such planning are encountered on other sites of the Late Roman period too (Fig.8); 2. Generally, almost everywhere barracks are longitudinal structures [J.J. McLaughlin, 2015:153, fig. 5). Consequently, attribution of a square-in-plan structure to a barrack is groundless.

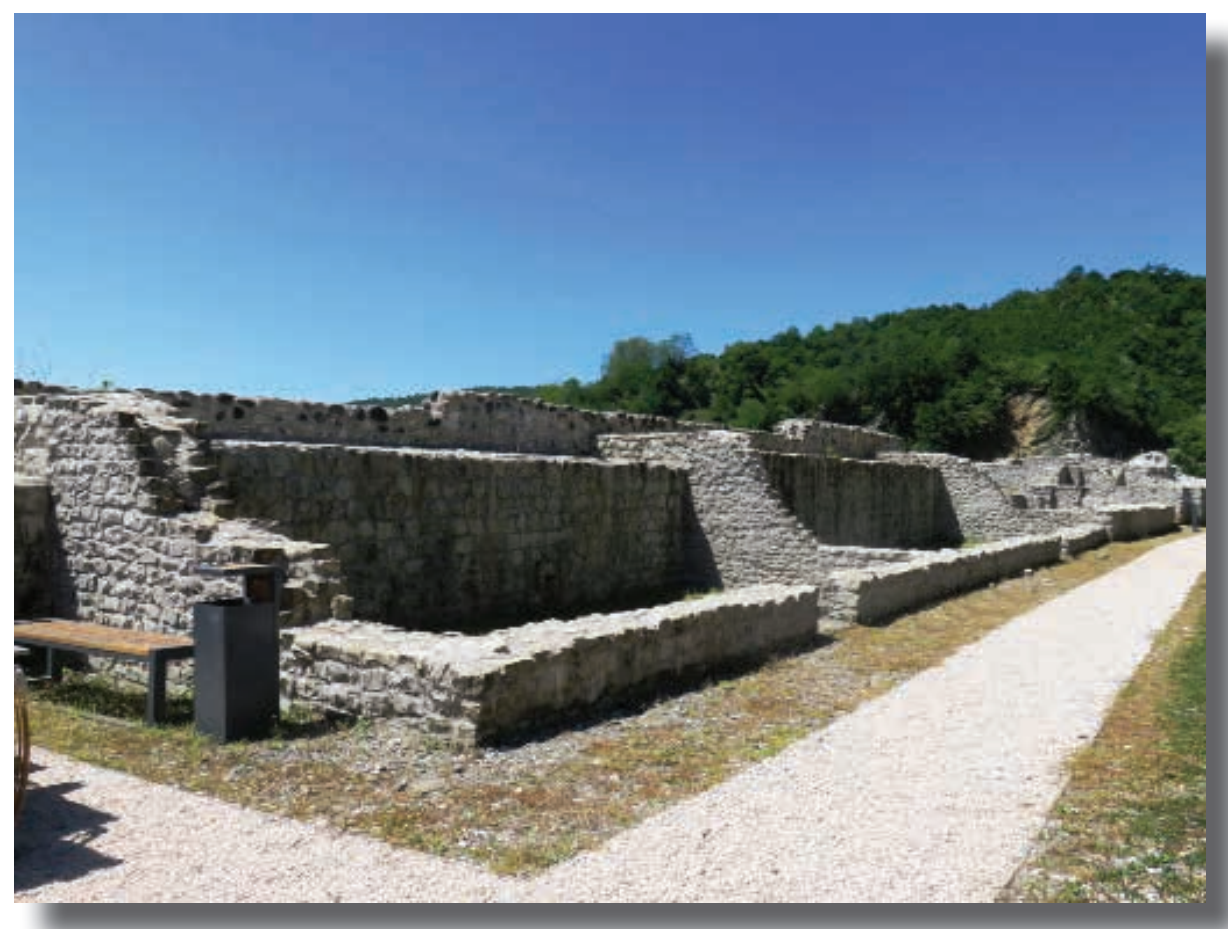

Fig. 3

Observation of the architecture of other city-sites of the Late Roman and Early Byzantine epochs led us to the conclusion that the structure revealed in the southeast part of Nokalakevi citysite with a high likelihood had a function similar to that of a praetorium or principium. In Roman camps and castra a praetorium was the residence of a military leader (general), later of the head of a city, while principium was military-administrative headquarters. Both structures are characterized by an almost square plan with several small-size rooms arranged on the edges, and a central hall or a yard. Plans of the praetoria of different Roman castles are provided below (Fig. 9). We believe that the plan of the structure revealed in Nokalakevi showes vivid similarity with these plans. 
Here we should once again go back to the question of establishing Nokalakevi as the capital of the kingdom of Egrisi. It has been repeatedly cited in scholarly literature that declaration of Nokalakevi as the capital was largely determined by military motifs, rather than by an economic necessity [Lomouri N. 1981:18-45; Леквинадзе В. А., Хведелидзе Л. И. 1981: 120-148]. The whole western Georgia, including newly annexed Apshileti, Abazgia and Svaneti, was controlled from Nokalakevi-Archaeopolis. Accordingly, it is only natural that powerful (and, probably, the most important both in terms of preparation and number) military divisions stood here, indeed, together with the leader. Presently, it is hard to identify whether this garrison and its leaders were Roman or local. However, it is obvious that along with churches and royal residences, the major military-administrative point of the country must have had a military-administrative facility too, which was probably arranged near the barracks. Noteworthy are accounts about presence of military divisions in Archaeopolis provided through written sources too. Stationing of a Byzantine garrison in Archaeopolis is also confirmed by Procopius of Caesarea and Agathias Scholasticus. While describing the events taking place in 551, Procopius writes: "The Roman army consisted of 12,000 soldiers and they were not gathered in one place only. There were 3,000 men in the army guarding Archaeopolis. They were led by Odonacus and Baba, who were both skilled in military affairs" [Procopius of Caesarea, 1965:183]. The same Baba led the whole Byzantine army in 555. According to Agathias Scholasticus of Myrina, when the tribe of the Dilimnites serving in the Iranian army attacked the Sabirs, hired by the Byzantines and camped in a village near Archaeopolis, the Byzantine commander was staying in Archaeopolis. Then Agathias writes: "Strategos Baba, who had long been commanding the Romans stationed in the country of Colchis, was staying in Archaeopolis that night and he could hear scream and noise from everywhere. As it was dark and hard to find out what was going on, he was also sitting silently in the castle. But when the sun lit the summits of the mountains, he clearly saw what was happenin. In particular, he saw that the Dilimnites were running away from the Sabirs, so he immediately rushed from the city together with the accompanying army and slaughtered quite a lot of the Dilimnites, so that as few as 1,000 men hardly reached Nakhoragan" [Agathias Scholasticus 1936:94-95]. Apparently, commanders of the Byzantine army were stationed in Archaeoplis. A later account provided by Theophanes the Chronicler also speaks about the military-strategic importance of Archaeopolis. While describing the events of 717, he recounts that at the time Archaeopolis was under the Arabs: after a while the Romans and Armenians invaded Lazike and besieged Archaeopolis. When they heard about the arrival of the Arabs, they retreated [Theophanes the Scholasticus 1941:110]. In this case, too, there is a high likelihood of presence of the commander of the Arab army in Archaeopolis. As a consequence of all the above mentioned it is presumable that the structure revealed in the south-east part of the Nokalakevi city-site in 1978 was the residence (and/or headquarters) of the commanders of the military divisions stationed in Archaeopolis, rather than the palace of the kings of Egrisi. This suggestion is also supported by its location, planning and, probably, the number of floors (two). It is the subject of special research where the royal palace had stood prior to the fourth century, before the large palace was built south of the three-nave basilica in the fifth century. In our opinion, remains of the first palace have to be sought nearby, in the royal district, but it is the subject of future investigations. 


\section{Reference}

1. Agathias Scholasticus, Georgica III, Greet text published with translation and interpretation by S. Kaukhchishvili, Tbilisi, 1936, pp. 23-187.

2. Dundua G., Cirghvava V., Eki hoard, in “Dzeglis Megobari”, 1971, № 27-28, pp. 42-45.

3. Zakaraia P., General report of the archaeological excavations in Nokalakevi 1978-1982, in Nokalakevi-Archaeopolis II. Archaeological excavations 1978-1982. “Metsniereba”, Tbilisi, 1987, Zakaraia, P. (ed).

4. Zakaraia P., The history of the Georgian fortresses, Tbilisi, 2002.

5. Zakaraia P., Kapanadze T., Cikhegoji-Archaeopolis-Nokalakevi, Architecture. Tbilisi, 1991.

6. Theophanes the Chronicler, Georgica IV, part 1, Greet text published with translation and interpretation by S. Kaukhchishvili, Tbilisi, 1941, pp. 264-270.

7. Lanchava O., Archaeology of Kutaisi, Kutaisi, 2007.

8. Lomouri N., Nokalakevi-Archaeopolis-Cikhegoji (Historical research), in Nokalakevi-Archaeopolis I. Archaeological excavations 1973-1977. "Metsniereba”, Tbilisi, 1981, Zakaraia, P. (ed).

9. Lomouri N., Interrelation of Georgia and Byzantine Empire, part 1 (IV-IX cc), Tbilisi, 2011.

10. Lortkipanidze B., The outward look of the city, in Nokalakevi-Archaeopolis III. Archaeological excavations 1983-1989. "Metsniereba”, Tbilisi, 1993, pp. 176-199.

11. Melikishvili G., Georgia in I-III centuries AD, in Studies of Georgian History, Vol. 1, Tbilisi, 1970, pp. 500569.

12. Murgulia N., The Chronology of the Construction of Nokalakevi-Archaeopolis, in "Bulletin of Caucasus", N16, Tbilisi, 2007, pp. 68-73.

13. Murgulia N., The fortification system of Egrisi Kingdom in 4th-6th centuries (According to the Archaeological materials and Historical sources). Dissertation work for the degree of Doctor of Archaeology. Tbilisi, 2012.

14. Muskhelishvili D., Georgia in IV and first half of V centuries, in History of Georgia in four volume, Vol 2, Tbilisi, 2012, pp. 7-48.

15. PPProcopius of Caesarea, Georgica II, Greet text published with translation and interpretation by S. Kaukhchishvili, Tbilisi, 1965, pp. 38-234.

16. LLLekvinadze, V. and Khvedelidze, L., Mass archaeological finds from excavations at Archaeopolis, in Zakaraia, P. (ed) Nokalakevi-Archaeopolis I. Archaeological excavations 1973-1977. "Metsniereba”, Tbilisi, 1981, pp. 120-148.

17. J. J. Mc Laughlin, The Transformation of the Roman Auxiliary Soldier in Thought and Practice, University of Michigan, 2015. 


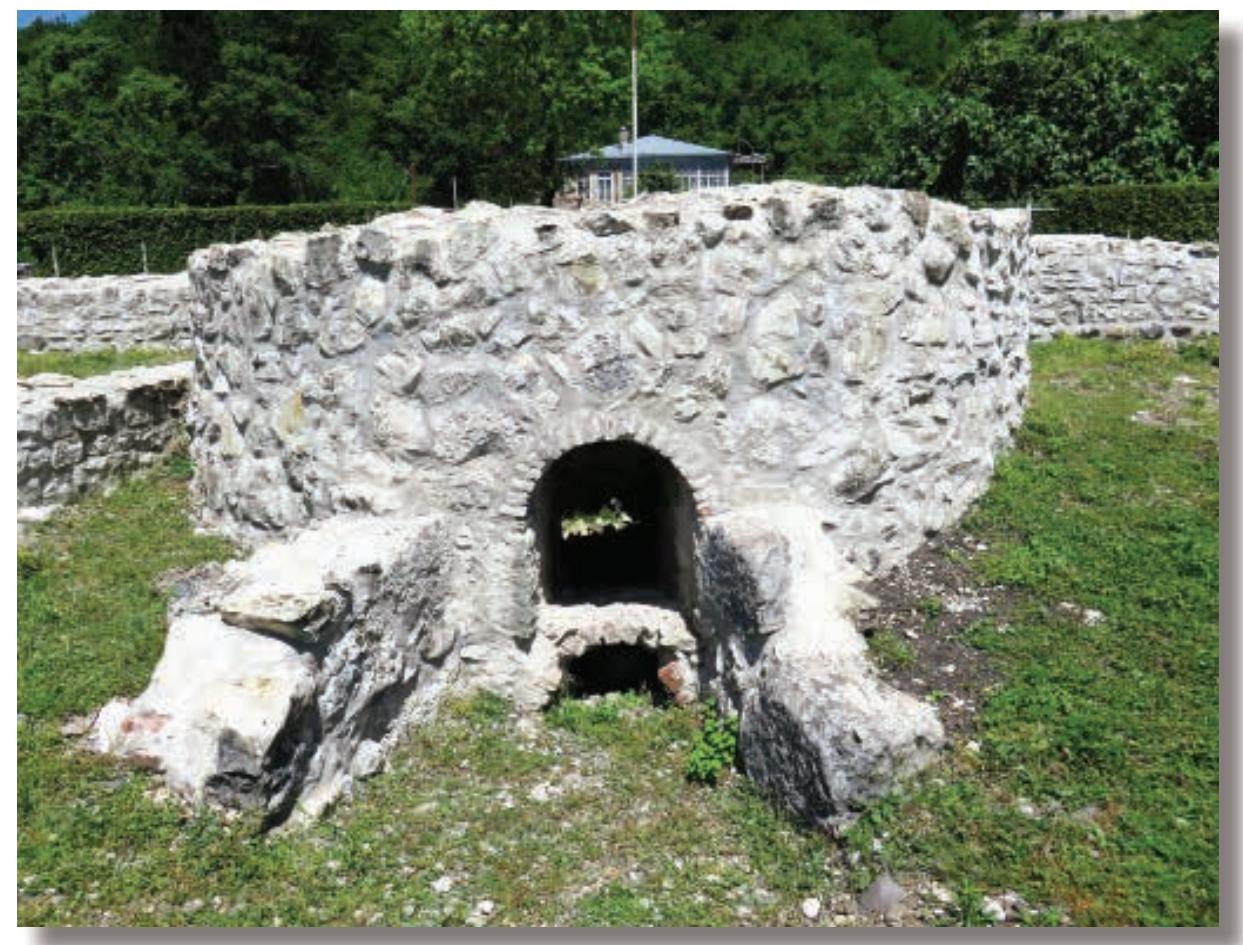

Fig. 4

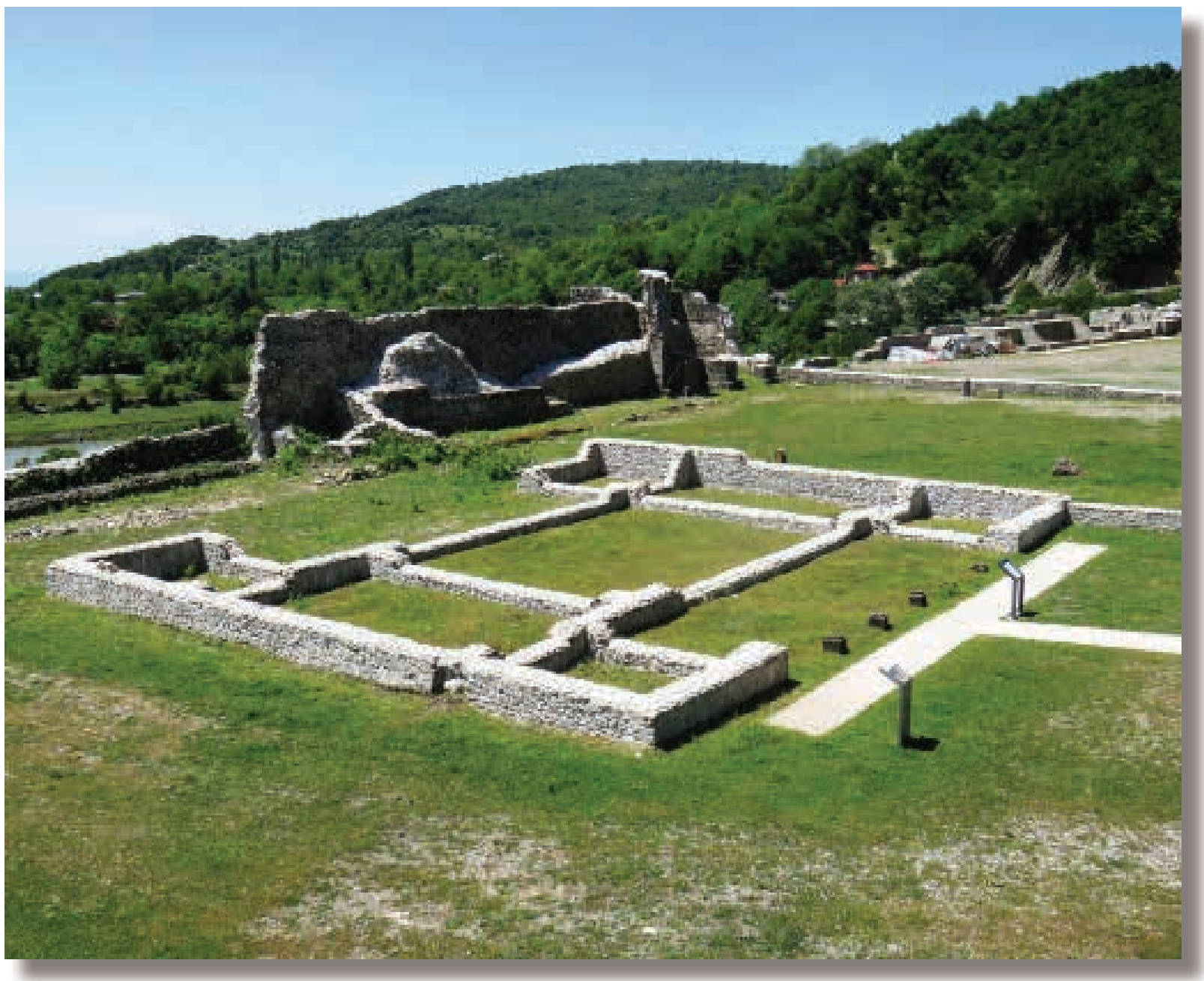

Fig. 5 


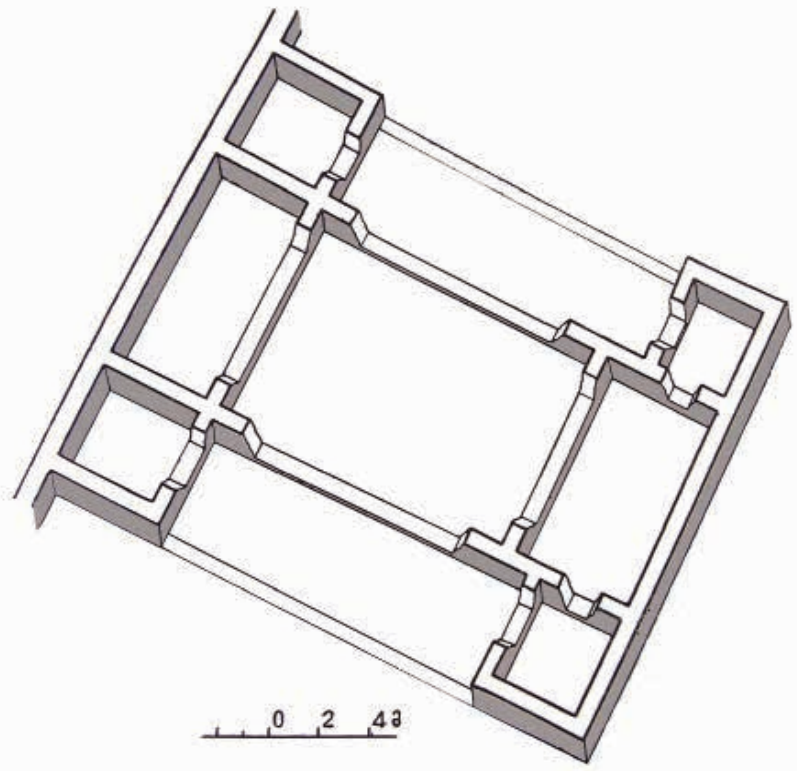

Fig. 6

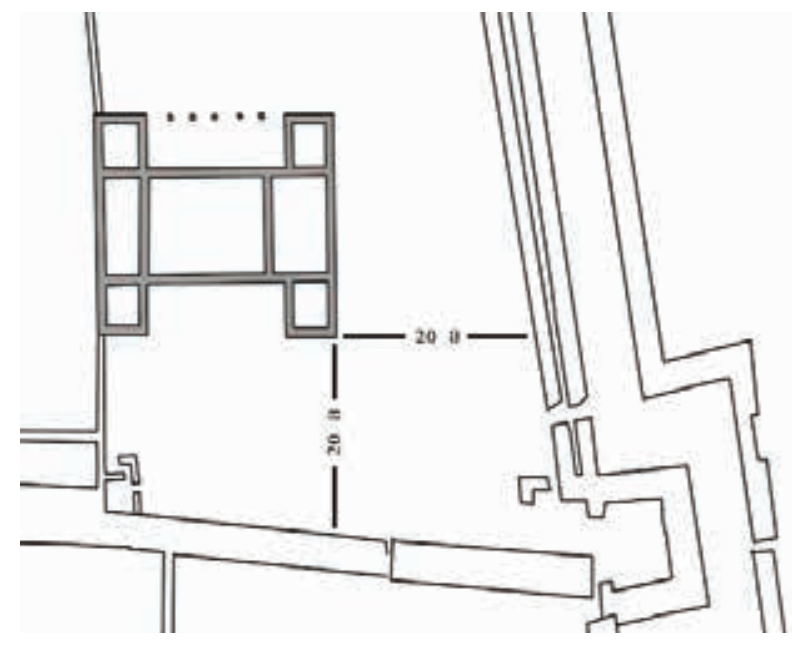

Fig. 7

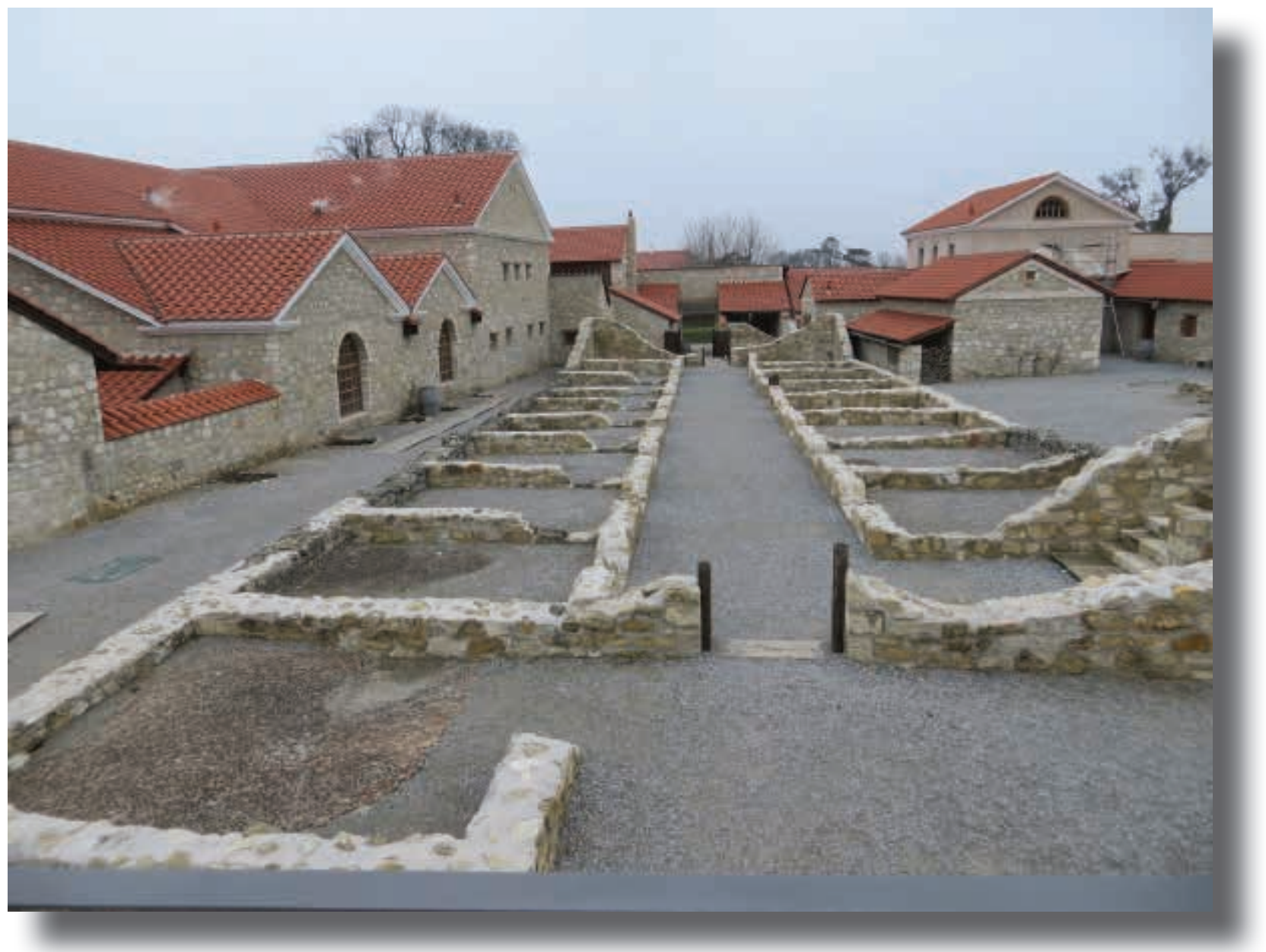

Fig. 8 

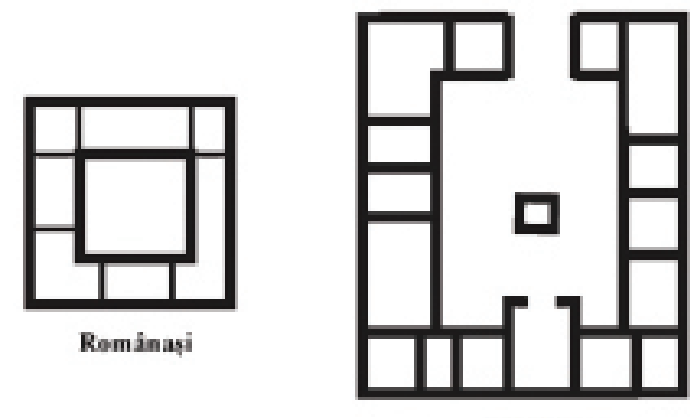

Remita_1

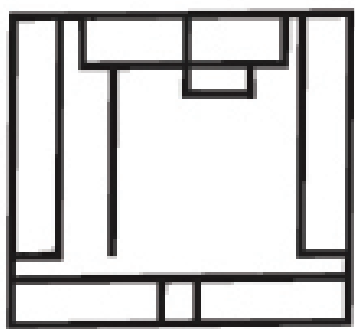

Remita_2

Fig. 9

\section{Description of illustrations:}

1. Map of the Caucasus in the $4^{\text {th }}-6^{\text {th }} \mathrm{cc}$.

2. General plan of Nokalakevi city-site.

3. Barracks in Nokalakevi. View from N-E.

4. Kiln for burning lime. View from S.

5. 'The first palace of the kings of Egrisi, or military headquarter/residence of the commander.

6. 'The first palace of the kings of Egrisi, or military headquarter/residence of the commander. Xonometry.

7. Plan of the S-E corner of the city-site, marking location of the structure.

8. Barracks of a Roman city of Carnuntum.

9. Plans of the praetoria of the Roman fortresses in western Dacia. 